\title{
Seroepizootiological investigation on Goat Warble Fly Infestation (Przhevalskiana silenus) in Pothwar Plateau, Pakistan
}

\author{
Liaquat, S. ${ }^{1}$, Qayyum, M. ${ }^{1}$, Ahmed, H. ${ }^{2}$, Arfeen, R.Z.U. ${ }^{3}$, Celik, F. ${ }^{4}$, Simsek, S. ${ }^{*}$ \\ ${ }^{1}$ Department of Zoology, PMAS Arid Agriculture University, Rawalpindi, 46000, Pakistan \\ 2Department of Biosciences, COMSATS University Islamabad (CUI), Islamabad, 46000, Pakistan \\ ${ }^{3}$ School of Food \& Agricultural Sciences, University of Management \& Technology(UMT), Lahore, Pakistan \\ ${ }^{4}$ Department of Parasitology, Faculty of Veterinary Medicine, University of Firat, TR-23119 Elazig - Turkey \\ *Corresponding author e-mail: ssimsek@firat.edu.tr
}

\section{ARTICLE HISTORY}

Received: 26 October 2020

Revised: 26 December 2020

Accepted: 31 December 2020

Published: 30 April 2021

\begin{abstract}
Goat Warble Fly Infestation (GWFI) is also known as subcutaneous myiasis caused by Przhevalskiana silenus (Diptera: Oestridae). It is widely distributed in tropical and sub-tropical areas of the world. In goats, WFI is usually detected through conventional procedure which underestimated the infestation. The current study was designed to determine the serodiagonsis of GWFI (through IDEXX Hypodermosis serum antibody test) and also aimed to investigate its seroepizootiological profile in Pothwar region, Pakistan from 2013-14. The results showed that average seropositivity (ELISA kit) of GWFI was $18.5 \%$ whereas, it was $11 \%$ by using conventional procedure (Palpation method) depicting a significant difference $(p<0.05)$. Higher seropositivity $(30.8 \%)$ was observed in Jhelum district as compared to e Attock district (6\%). The L1 larvae were found in September, while nodules start appearing in October to December and last until the end of February. The month wise peaks of optical density (OD) was higher in December which gradually decrease along with the end of winter season. The prevalence of GWFI revealed no significant difference among three host breeds (Jattal, Beetal and Tedy). According to the results, high infestation rate (28\%) was observed in young animals of age group $<1$ year as compared to old animals ( $>2$ years). Topographically, hilly areas (33\%) provide favourable climatic conditions for the propagating of larval stages. Sex difference showed no significant difference. The seroprevalence varied significantly with respect to age, month, districts and topographical location. The current study proved that serologic diagnosis (commercial ELISA kit) as more sensitive and accurate for timely diagnosis of GWFI than traditional method. The information on the epizootiology of $P$. silenus in goats of Pothwar region would help in devising effective control strategies.
\end{abstract}

Keywords: GWFI, Przhevalskiana silenus, serodiagnosis, seroprevalence, Pothwar Plateau, Pakistan

\section{INTRODUCTION}

Livestock is the backbone of the country like Pakistan where majority of the population especially in the rural area depends upon the agriculture sector. There are different factors responsible for low production in the livestock sector. One of them are ectoparasitic infestations throughout the world (Hourrigan, 1979). Among these, myiasis caused by Hypoderma species (larvae) is considered as an economically important menace in wild and domesticated ruminants. The definitive herbivore host of this parasite include buffalo, cattle, deer, reindeer, sheep and goat (Scholl, 1993). In Pakistan, warble fly infestation (WFI) is mainly reported from mountainous and semi-hilly parts in large ruminants (Shah, 1981; Hasan et al., 2007) and in goats (Khan, 1997). Despite, the physical impairment; myiasis harm the internal organs and also affects the host's immunity. In Europe and North America, this infestation was significantly reduced by chemotherapeutic treatments against the first larval stage and adults of the parasitic fly (Boulard, 2002).

Detection of infested goats by clinical examination (hand palpation) generally render the hypodermosis unrecognized (Sinclair et al., 1984). The accurate and rapid diagnosis of etiological agents and characterization of parasites based on epidemiologically useful features are necessary for the control of veterinary parasitic diseases. Throughout the world, many serological assays immunoelectrophoresis, indirect haemagglutination, and gel diffusion have been developed for early diagnosis of WFI (Balkaya et al., 2010).

Indeed, Enzyme Linked Immunosorbent Assay (ELISA) resolved the difficulty of timely detection of infestation prior to the sign of protuberances and is extensively practiced 
because of its accuracy (Otranto et al., 2001). In this assay, hypodermal antigen ( $1^{\text {st }}$ instar) is used for antibodies detection in infested sera (Boulard \& Moiré, 2004). It is well recognized in U.K, where hypodermosis was successfully eradicated through the application of ELISA (Webster et al., 1997). The serodiagnosis of WFI by commercial ELISA kit (IDEXX Hypodermosis serum antibody test) (Otranto et al., 1999; Faliero et al., 2001; Otranto et al., 2005), basically developed for bovine hypodermosis, confirmed cross-reactivity between Hypoderma lineatum antigen and anti- $P$. silenus antibodies and validated for use in goats (Morsy et al., 1999; Domínguez et al., 2010; Panadero et al., 2010; Puente et al., 2010).

Goats are considered as poor men's cow in Pothwar region as they help to augment income of rural population. Despite the extensive problem caused by warble fly, the information on serodiagonsis and epidemiological profile of GWFI is not well defined in this region. All previous investigations in the study area were based on traditional palpation procedure and therefore unable to diagnose disease at early stages. This necessitated the need of reliable and efficient diagnostic technique for GWFI to minimize economic losses to the livestock sector of Pakistan.

Therefore, present study was designed with following objectives in Pothwar region, Punjab, Pakistan:- (1) Estimation of seroprevalence of $P$. silenus infestation in goats by serologic diagnosis (commercial ELISA kit) and comparison with traditional method (2) To explore potential risk factors for designing eradication platform for the infestation.

\section{MATERIALS AND METHODS}

\section{Study Area}

The current serological investigation was carried out among goats of Pothwar region of Punjab, Pakistan. This region, comprises of four districts; Attock ( $355 \mathrm{~m})$, Jhelum $(233 \mathrm{~m})$, Rawalpindi $(508 \mathrm{~m})$ and Chakwal $(498 \mathrm{~m})$ is located at latitude $30^{\circ}-34^{\circ} \mathrm{N}$ and longitude $70^{\circ}-74^{\circ} \mathrm{E}$ in the northern Punjab province. It is a rain-fed zone covering an area of about 13,000 $\mathrm{km}^{2}$, representing $2.9 \%$ of the country. The Jhelum and Indus River bounded the east and west, while the Kala Chita Range, Salt Range and Murree Hills are on northern and southern side of Pothwar Plateau, having an overall plain to moderately undulating ground, separated by valleys and hills, making the area suitable as pasture land. Climatically, Pothwar Plateau is a sub-tropical continental with erratic rainfall pattern received about $60-70 \%$ of the total rainfall (Nizami et al., 2004) and average temperature of $22.5^{\circ} \mathrm{C}$. The altitude and agriculture practices in the selected area support the breeding system of warble fly.

\section{Experimental design}

A total of 1000 goats belonging to three different breeds (Jattal, Beetal and Tedy) were examined for the seroprevalence during April 2013 to March 2014. Proportional sampling (100 samples per month) was done based on three different categories (houses, farm houses and veterinary hospitals). The random sampling was done from different areas of four selected districts (Rawalpindi, Jhelum, Attock and Chakwal) of Pothwar region.

\section{Detection/Diagnosis}

\section{Morphological diagnosis}

From April 2013 to March 2014, several flocks (ranged from 10-300 heads per flock), were examined visually as well as hand palpation at back and flank region for the presence of nodules or lesions. The number of nodules were counted to measure the intensity of infestation.

\section{Serologic diagnosis}

For serodiagnosis, the blood samples (1000) were taken from selected animals on monthly basis (regardless of infestation) during the study period. The blood samples were collected from jugular vein of animal using by disposable syringe in non-EDTA coated vacutainer $(10 \mathrm{ml})$. The serum was separated and stored at $-20^{\circ} \mathrm{C}$ for further analysis. Clinically, 100 infested goats with prominent nodules were selected for collection of positive sera, while the negative sera were taken from Lancaster goats, Veterinary Genes and Proteins Laboratory, University of Glasgow, Scotland. The serological test, using commercial ELISA kit was performed according to the prescribed protocols (IDEXX Bovine Hypodermosis Antibody Kit), sensitivity and specificity values were also calculated (Otranto et al., 1999; Faliero et al., 2001; Otranto et al., 2005). The optical density (OD) was recorded at the wavelength of $450 \mathrm{~nm}$.

\section{Epizootiological factors}

A questionnaire, based on epizootiological information (age, sex, breed, district, month and topography) was used. The goats were categorized into three age clusters i.e., < 1yr, 1-2 $\mathrm{yr}$ and $>2 \mathrm{yr}$ old, on the basis of incisor teeth (Khan, 1969). The phenotypic characteristics were considered for breed identification (Hasnain, 1985).

\section{Statistical analysis}

The results were analysed by using Pearson's chi-squared $\left(\chi^{2}\right)$ test followed by post hoc test (Z-test) with Bonferroni correction in SPSS version 20.0.

\section{RESULTS}

The serologic analysis by IDEXX hypodermosis serum ELISA kit and manual palpation procedure were compared for early diagnosis of GWFI from four districts of Pothwar region, Punjab, Pakistan. The sensitivity and specificity of ELISA kit was $90 \%$. The prevalence was $18.5 \%$ (185/1000) and $11 \%(110 / 1000)$ by ELISA kit and palpation method, respectively. Higher prevalence of $30.8 \%$ and $16.8 \%$ was found in Jhelum district while Attock district showed the lowest infestation rate of $6 \%$ and $5.2 \%$ for commercial ELISA Kit and conventional method, respectively (Table 1 \& Fig. 1). Both the diagnostic methods showed significant difference $(p<0.05)$ in the prevalence of GWFI between the four districts.

The prevalence of GWFI, by serological and conventional method in different months revealed a significant difference. Both diagnostic methods showed high prevalence $(44 \%)$ in December as shown in Table 2 \& Fig. 2. The $1^{\text {st }}$ instar larvae were found from July-September, $2^{\text {nd }}$ instar larvae from midSeptember to November and $3^{\text {rd }}$ instar larvae were seen from December to February. The nodules start appearing in October to December and last until the end of February. Month-wise analysis by ELISA showed peak in optical density (OD) values in December which gradually decreases with the end of winter season.

According to sex, the prevalence by conventional method was $11 \%(63 / 572)$ and $10.98 \%(47 / 428)$ whereas, ELISA kit showed $18.8 \%(108 / 572)$ and $17.9 \%(77 / 428)$ seroprevalence in female and male animals, respectively (Table 3 \& Fig. 3 ). High seroprevalence rate was observed in females than males. 
Liaquat et al. (2021), Tropical Biomedicine 38(2): 1-8

Table 1. District wise prevalence of GWFI using commercial ELISA kit and conventional palpation method in Pothwar Region, Punjab, Pakistan

\begin{tabular}{|c|c|c|c|c|c|c|c|}
\hline \multirow{3}{*}{ District } & \multirow{3}{*}{$\begin{array}{l}\text { Animal } \\
\text { Examined }\end{array}$} & \multicolumn{6}{|c|}{ Diagnostic Methods } \\
\hline & & \multicolumn{3}{|c|}{ Conventional method } & \multicolumn{3}{|c|}{ Commercial ELISA kit } \\
\hline & & Non-infested & Infested & Percentage (\%) & Non-infested & Infested & Percentage (\%) \\
\hline Rawalpindi & 250 & 215 & 35 & $14 \%$ & 189 & 61 & $24.4 \%$ \\
\hline Jhelum & 250 & 208 & 42 & $16.8 \%$ & 173 & 77 & $30.8 \%$ \\
\hline Attock & 250 & 237 & 13 & $5.2 \%$ & 235 & 15 & $6 \%$ \\
\hline Chakwal & 250 & 230 & 20 & $8 \%$ & 218 & 32 & $13 \%$ \\
\hline Total & 1000 & 889 & 110 & $11 \%$ & 815 & 185 & $18.5 \%$ \\
\hline
\end{tabular}

Chi-square $\left(\chi^{2}\right)$ Test: Hand palpation $(F=20.6, d f=3, p<(0.05)$.

Chi-square $\left(\chi^{2}\right)$ Test: Commercial ELISA kit $(F=62, \mathrm{df}=3, \mathrm{p}<(0.05)$.

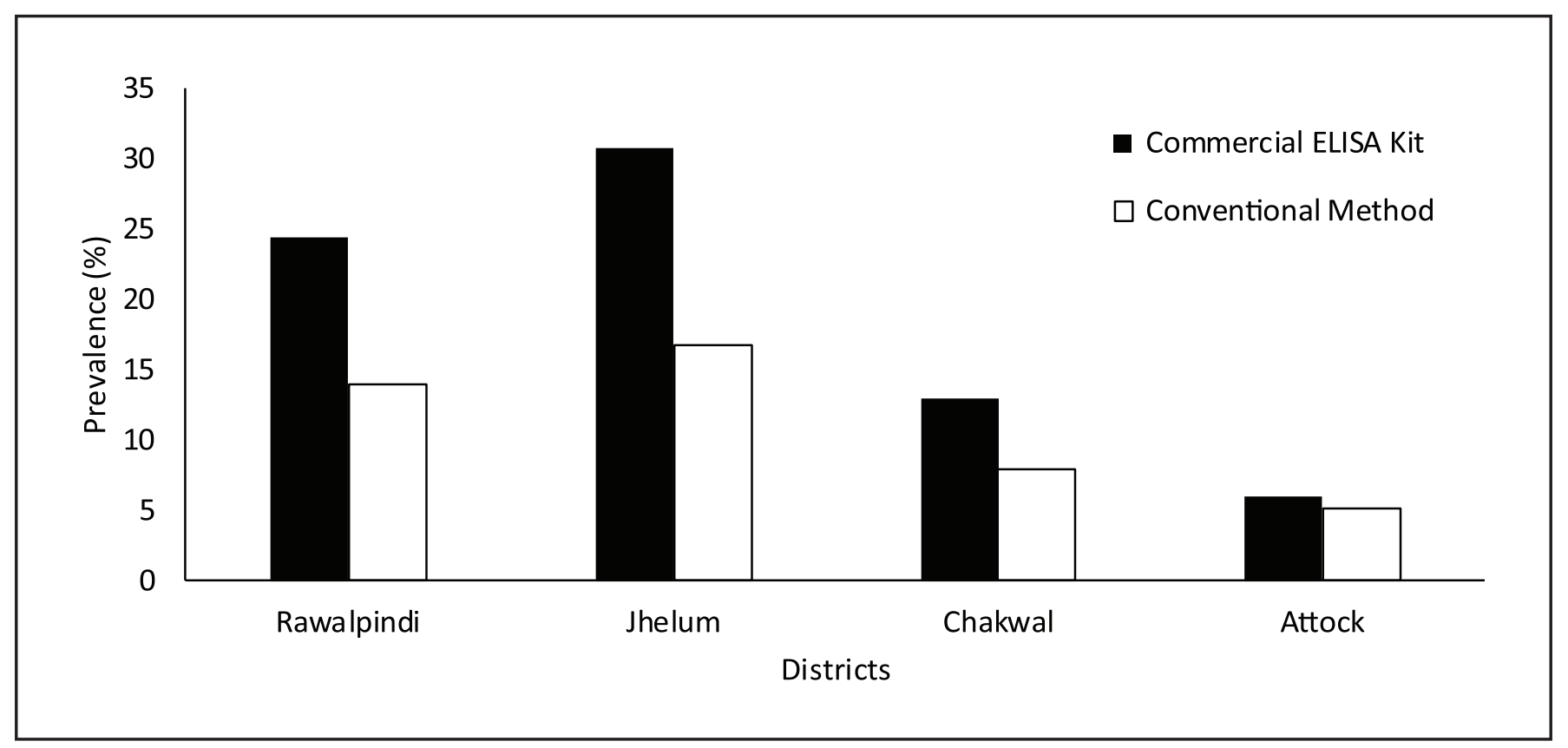

Figure 1. District wise prevalence of GWFI by conventional and commercial ELISA kit method in Pothwar region, Pakistan.

Table 2. Month wise prevalence of GWFI in Pothwar region, Pakistan (2013-14)

\begin{tabular}{lcccc}
\hline Month & $\begin{array}{c}\text { Animal } \\
\text { examined }\end{array}$ & Positive & $\begin{array}{c}\text { Percentage } \\
(\%)\end{array}$ & Z-test \\
\hline June (A) & 100 & 0 & 0 & \\
July (B) & 100 & 0 & 0 & \\
August (C) & 100 & 0 & 0 & \\
September (D) & 100 & 0 & 0 & E, I, J \\
October (E) & 100 & 7 & 7 & E, F, I, J \\
November (F) & 100 & 21 & 21 & \\
December (G) & 100 & 44 & 44 & \\
January (H) & 100 & 29 & 29 & \\
February (I) & 100 & 8 & 1 & \\
March (J) & 100 & 1 & & \\
\hline Total & 1000 & 110 & $11 \%$ & \\
\hline
\end{tabular}

Z-test, revealed the prevalence of GWFI in month of Nov. $(F)$ and Jan. $(H)$, vary significantly from Oct. (E), Feb. (I) and Mar.(J): whereas, Dec. has maximum prevalence $(44 \%)$.
The prevalence of GWFI in three age groups $(<1 \mathrm{yr}, 1-2 \mathrm{yr}$ and $>2 \mathrm{yr}$ ) using traditional method was $16.4 \%$ (85/518), $6.5 \%$ $(15 / 231)$ and $4 \%(10 / 251)$, respectively while seroprevalence based on ELISA kit was $28 \%$ (144/518), 10.8\% (25/231) and 6.4\% $(16 / 251)$ in $<1$ year, 1-2year and $>2$ year, respectively (Table 3 \& Fig. 4). According to the results, higher infestation was observed in goats of age group $(<1$ year) as compared to animals ( $>2$ years) in all studied areas. Breed wise prevalence was investigated on monthly basis. Statistically, no significant relation was found in the prevalence and seroprevalence of GWFI between the breeds (Jattal, Beetal and Tedy). High prevalence of breeds by clinical method was $12 \%(41 / 349)$ whereas the serodiagnosis revealed the prevalence of $21.2 \%$ (74/349) in beetal breed (Table 3 \& Fig. 5).

Topographically, three different locations viz., plain, hilly and semi-hilly were surveyed. The prevalence by palpation method was $9.5 \%(24 / 253), 30.5 \%(22 / 72)$ and $9.5 \%(64 / 675)$ in plain, hilly and semi-hilly areas, respectively. Whereas, the three topographical locations showed the seroprevalence of $14 \%(35 / 253), 33.3 \%(24 / 72)$ and $19 \%(126 / 675)$, respectively (Table 3 \& Fig. 6). 


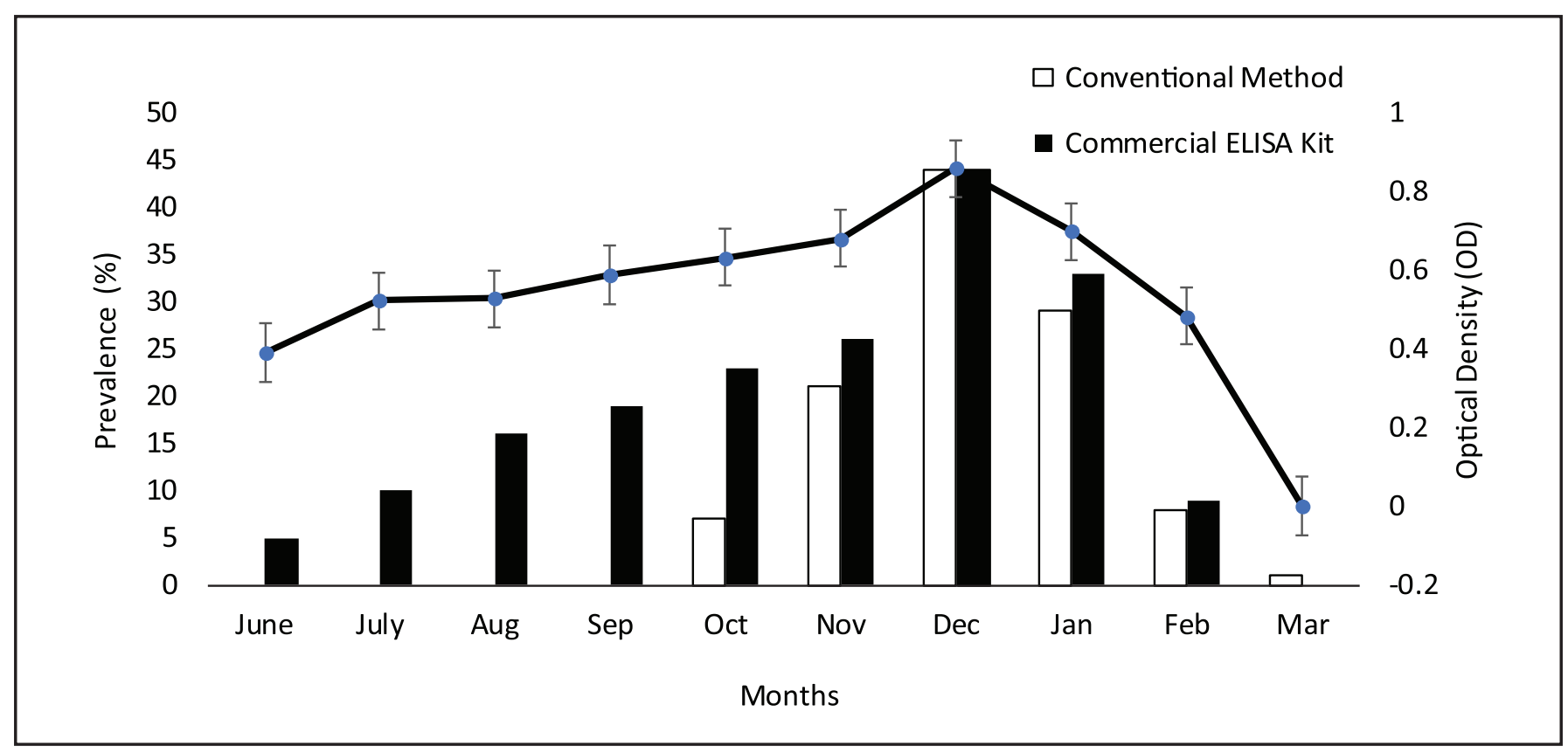

Figure 2. Month wise prevalence of GWFI by conventional and commercial ELISA kit method in Pothwar region, Punjab, Pakistan.

Table 3. Possible risk factors for the seropositivity of GWFI and their $p$-values based on Chi-square analysis $\left(\chi^{2}\right)$

\begin{tabular}{|c|c|c|c|c|c|c|c|c|}
\hline \multirow{3}{*}{ Factor } & \multirow{3}{*}{ Level } & \multirow{3}{*}{$\begin{array}{l}\text { Examined } \\
\text { animals }\end{array}$} & \multicolumn{6}{|c|}{ Diagnostic Techniques } \\
\hline & & & \multicolumn{3}{|c|}{ Palpation method } & \multicolumn{3}{|c|}{ ELISA } \\
\hline & & & $\begin{array}{l}\text { Non-infested } \\
\text { animals }\end{array}$ & $\begin{array}{l}\text { Infested } \\
\text { animals }\end{array}$ & $\mathrm{p}$-value & $\begin{array}{l}\text { Non-infested } \\
\text { animals }\end{array}$ & $\begin{array}{l}\text { Infested } \\
\text { animals }\end{array}$ & $\mathrm{p}$-value \\
\hline \multirow[t]{2}{*}{ Sex } & Male & 428 & 381 (89.1\%) & 47 (10.9\%) & $p=0.98$ & 350 (82.1\%) & 77 (17.9\%) & $p=0.89$ \\
\hline & Female & 572 & 509 (89\%) & $63(11 \%)$ & & 464 (81.2\%) & $108(18.8 \%)$ & \\
\hline \multirow[t]{3}{*}{ Age } & $<1 \mathrm{yr}$ & 518 & 433 (83.6\%) & $85(16.4 \%)$ & $p<0.05$ & $374(72 \%)$ & $144(28 \%)$ & $p<0.05$ \\
\hline & $1-2 y r$ & 231 & 216 (93.5\%) & $15(6.5 \%)$ & & 206 (89.2 \%) & $25(10.8 \%)$ & \\
\hline & $>2 y r$ & 251 & $241(96 \%)$ & $10(4 \%)$ & & 235 (93.6\%) & $16(6.4 \%)$ & \\
\hline \multirow[t]{3}{*}{ Breed } & Jattal & 245 & $220(90 \%)$ & $25(10 \%)$ & $p=0.83$ & $210(86 \%)$ & 35 (14\%) & $p=0.11$ \\
\hline & Beetal & 349 & $308(88 \%)$ & $42(12 \%)$ & & 275 (78.8\%) & 74 (21.2\%) & \\
\hline & Tedy & 406 & $362(89 \%)$ & $44(11 \%)$ & & 330 (81.3\%) & 76 (18.7\%) & \\
\hline \multirow[t]{3}{*}{ Topography } & Plain & 253 & 229 (90.5\%) & $24(9.5 \%)$ & $p<0.05$ & $218(86 \%)$ & 35 (14\%) & $p<0.05$ \\
\hline & Hilly & 72 & 50 (69.5\%) & $22(30.5 \%)$ & & $48(66.7 \%)$ & 24 (33.3\%) & \\
\hline & Semi-hilly & 675 & $611(90.5 \%)$ & $64(9.5 \%)$ & & $549(81 \%)$ & $126(19 \%)$ & \\
\hline \multirow[t]{2}{*}{ Season } & Summer & 400 & 400 (100\%) & 0 & $\mathrm{p}<0.05$ & 350 (87.5\%) & $50(12.5 \%)$ & $p<0.05$ \\
\hline & Winter & 600 & 490 (81.6\%) & $110(18.4 \%)$ & & 465 (77.5\%) & $135(22.5 \%)$ & \\
\hline
\end{tabular}

\section{DISCUSSION}

In current study, higher seroprevalence was reported by using ELISA Kit (IDEXX Hypodermosis serum antibody test) than conventional method in Pothwar region of Pakistan. This difference might be due to antibody mediated host immuneresponse, as the first instar larvae detected by ELISA, at early stage were later killed by the host defence system and consequently remain undetected on manual examination. Our results correlates with previous findings reported from different areas of Pakistan (Shah, 1981; Arshad et al., 2014) and other parts of the world (Otify \& Mansour, 1994; AboShehada et al., 2006; Oryan et al., 2009). However, no previous study by using serological assays was conducted yet on GWFI in Pothwar region, Pakistan.
The results confirmed the efficacy of Hypodermosis ELISA kit for GWFI. Our findings were in accordance with Navidpour et al. (2007), reported the sensitivity and specificity of $86.66 \%$ and $98.87 \%$, respectively.

The variation in prevalence rate among the districts might be due to management system, grazing patterns, pastures and use of insecticides. Similar findings were reported by Ahmed et al. (2012) and Arshad et al. (2014). The month wise study supported biological cycle as December has highest the seroprevalence whereas, prior to June no antibodies were observed in the animal body, as hypodermosis was in different development stage. Serologically, the WFI was seen in sera samples from June and July (summer season, $12.5 \%$ ). Whereas, manually the warble fly infestation was found in November until February (winter, 


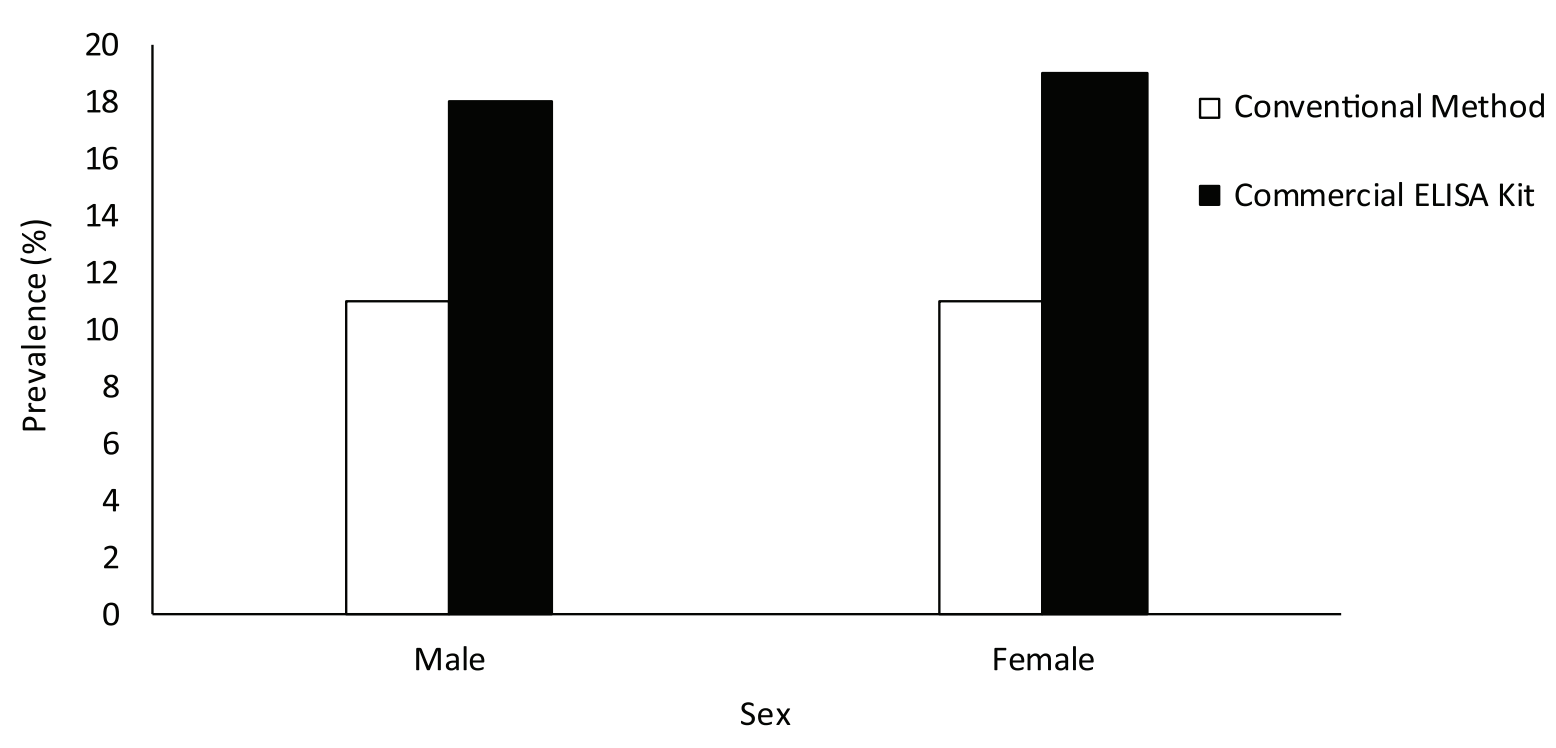

Figure 3. Sex based prevalence of GWFI by conventional and commercial ELISA kit method in Pothwar region, Punjab, Pakistan.

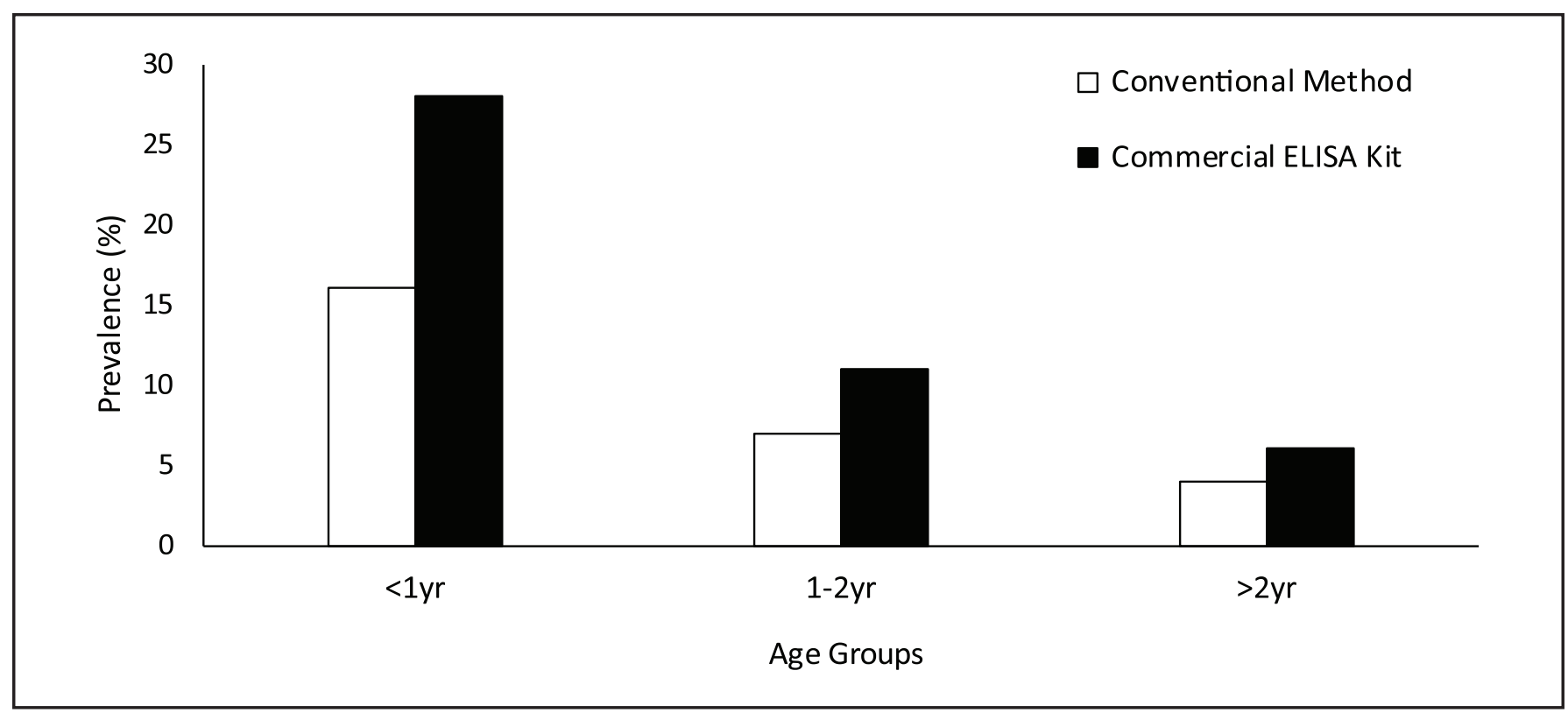

Figure 4. Age wise prevalence of GWFI by conventional and commercial ELISA kit method in Pothwar region, Pakistan.

18.4\%) after appearance of nodules on the flank and back of the goats. The highest infestation in the month of December may be attributed to the presence of third stage larvae in infested animals. The skin perforation appeared in January and nodule number began to disappear in February resulting in decreased infestation rate in March, indicating pupation period in the region. These findings were in conformity with other studies (Khan et al., 1994; Khan et al., 2006; Oryan et al., 2009; Tavassoli et al., 2010; Yadav et al., 2011).

The prevalence of warble fly infestation regarding epizootiological factors like age, breed, topography and season was monitored. The clinical and sub-clinical methods revealed no difference among both sexes. Our research findings were in line with previous studies (Rahbari \& Ghasemi, 1997; Yadav et al., 2006; Oryan et al., 2009; Domínguez et al., 2010; Oryan \& Bahrami, 2012; Arshad et al., 2014; Jan et al., 2014).
The prevalence of GWFI among different host breeds was monitored, showing low infestation in Jattal (Hairy) breed. The reason of lower prevalence in Jattal breed might be that they were kept as small flock by marginal farmers in Punjab or either kept on partial grazing and stall feeding. Whereas, in Punjab Tedy and Beetal goat breeds are preferred over Jattal by farmers and kept on free grazing making them prone to more infestation. Previously, no significant difference among the breeds was detected (Tavassoli et al., 2010; Radfar \& Hajmohammadi, 2012). In contrary, higher infestation in Desi (Tedy) breed might be due to their weak immune response (Arshad et al., 2014). Further investigations are required to evaluate the immunity of each breed against GWFI.

Among different age groups, higher seropositivity was observed in young animals of age group ( $<1$ year) as compared to older animals ( $>2$ years) in all studied areas revealing 


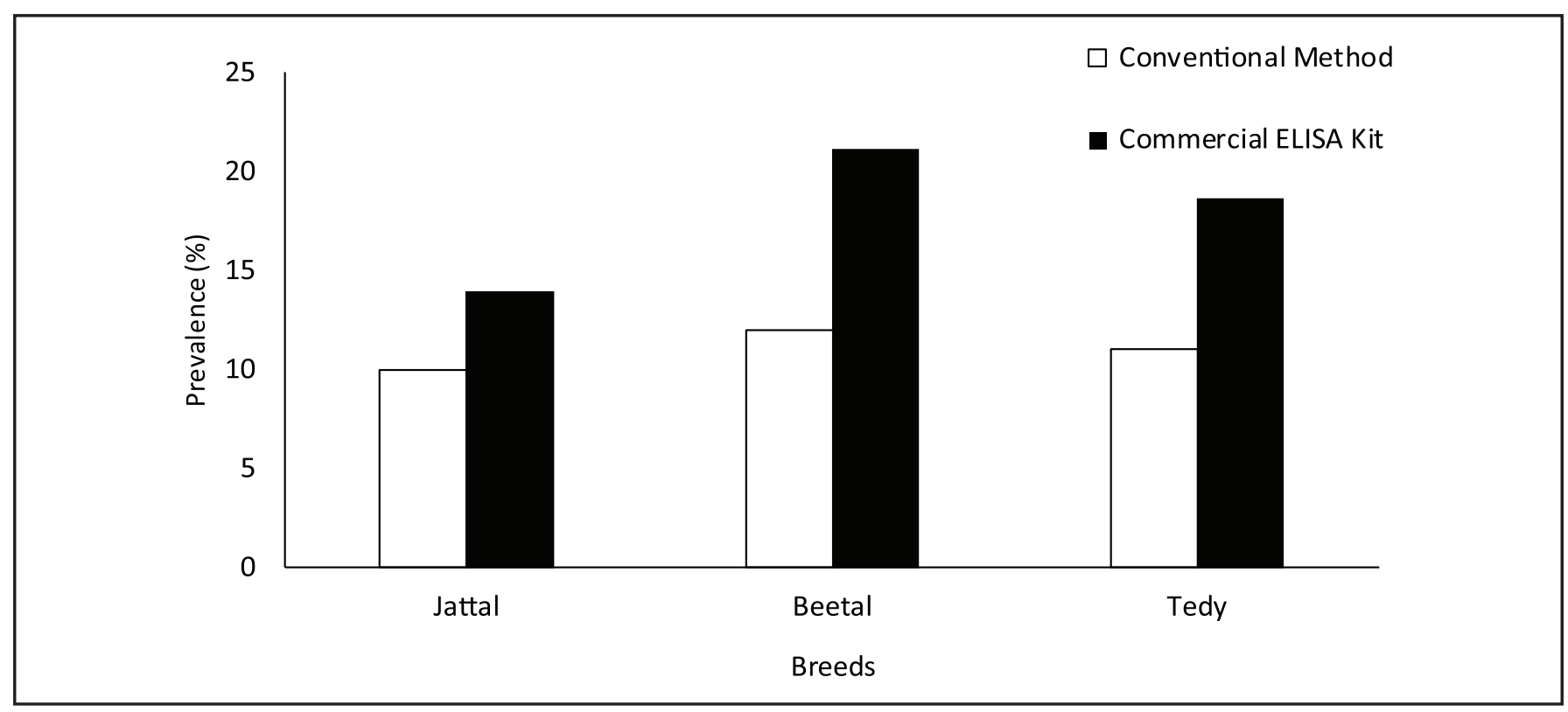

Figure 5. Breed wise prevalence of GWFI by conventional and commercial ELISA kit method in Pothwar region, Pakistan.

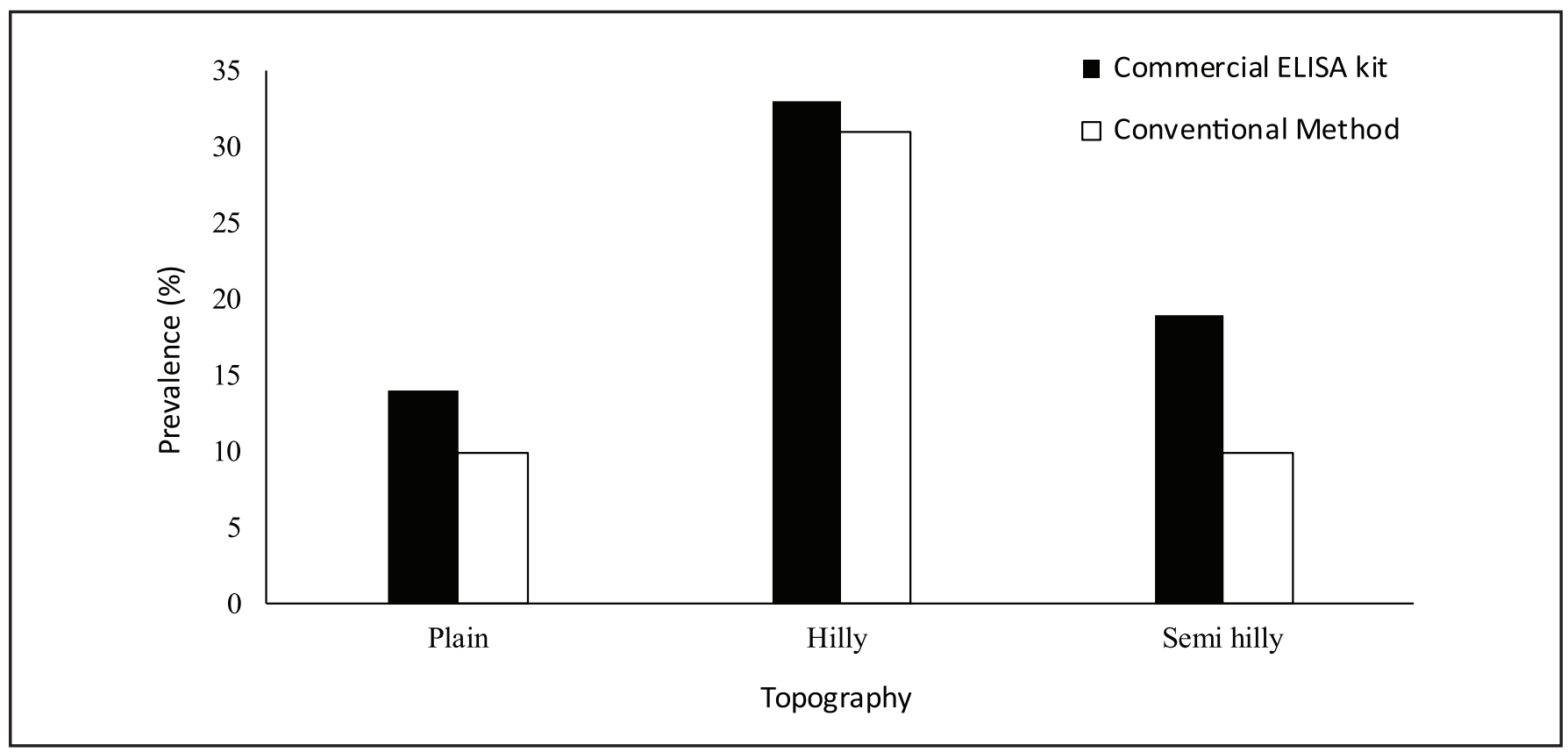

Figure 6. Location wise prevalence of GWFI by conventional and commercial ELISA kit method in Pothwar region, Pakistan.

a significant different $(p<0.05)$. Our findings of lower prevalence in older animals were in accordance with the previous studies (Otranto \& Puccini, 2000; Oryan et al., 2009; Hassan et al., 2010; Arshad et al., 2014) whereas, low seropositivity in the animals over 3 years of age could be attributed to the development of acquired resistance in response to previous exposure (Oryan et al., 2009; Hassan et al., 2010; Jan et al., 2014). According to Oryan et al. (2009), higher number of infested young goats might be due to their soft skin as compared to the hard and thicker skin of older animals, which serve as a barrier for the penetration of larvae.

Topographically, higher seroprevalence of warble fly infestation was observed in mountainous and semi mountainous lands compared to the plain areas. Higher infestation in hilly areas might be due to favourable climatic conditions for the larval stages while in mountainous and semi mountainous areas, the agricultural practices were not common as practiced in plain areas. Similar findings were reported by Hasan et al. (2007) while in contrary to our findings (Khan et al., 1997; Ayaz, 1998; Jan et al., 2014) reported the variation in prevalence rate.

Commercial ELISA kit, developed for bovine hypodermosis proved a useful diagnostic tool for detection of GWFI at the earlier developmental phase in which animals having antibodies in their blood and without having any nodule or lesion. Whereas, the traditional palpation method diagnosis the infestation at the later stage when too much damage has been done.

It is concluded from the present study that ELISA tool was more specific, effective and accurate diagnostic method than traditional palpation procedure. The age of animal, 
season and location were the potential risk factors for GWFI. It is strongly recommended to separate the animals found infected through ELISA test for timely treatment, as not to perpetuate the condition. It is also required to find seroprevalence and risk factors from other areas of the country that helps to reveal the exact status of the infestation in the country.

\section{ACKNOWLEDGEMENTS}

This study was funded by IRSIP program of Higher Education Commission (HEC), Pakistan.

\section{Conflict of interest}

The authors have no competing interests to declare.

\section{REFERENCES}

Abo-Shehada, M.N., Batainah, T., Abuharfeil, N. \& Torgerson, P. (2006). Przhevalskiana silenus myiasis among slaughter goats in northern Jordan. Veterinary Parasitology 137: 345350. https://doi.org/10.1016/j.vetpar.2006.01.014

Ahmed, H., Khan, M.R., Fontan, R.P., Sandez, C.L., Iqbal, M.F., Naqvi, S.M.S. \& Qayyum, M. (2012). Geographical distribution of Hypodermosis (Hypoderma spp.) in Northern Punjab, Pakistan. Kafkas Universitesi Veteriner Fakultesi Dergisi 18: 215-219. https://doi.org/10.9775/ kvfd.2012.6533

Arshad, M., Siddique, F., Ahmad, S., Mustafa, I., Nasir, M.F., Anwar, P., Asif, S., Khan, M.R., Hussain, M. \& Ahmed, H. (2014). An epidemiological study on prevalence of Goat Warble Fly Infestation (GWFI) from Punjab Province, Pakistan. Kafkas Universitesi Veteriner Fakultesi Dergisi 20: 35-40. https://doi.org/10.9775/kvfd.2013.9402

Ayaz, M.M. (1998). Prevalence and treatment of goat warbles in Fort Munro and akni, Pakistan. Pakistan Veterinary Journal 18: 162-164.

Balkaya, I., Simsek, S. \& Saki, C.E. (2010). A serological and molecular survey of cattle hypodermosis in east-Turkey. Veterinary Parasitology 173: 287-291. https://doi.org/10.1016/ j.vetpar.2010.07.009

Boulard, C. (2002). Durably controlling bovine hypodermosis. Veterinary Research 33: 455-464. https://doi.org/10.1051/ vetres:2002032

Boulard, C. \& Moiré, N. (2004). Humoral response during the course of hypodermosis. Chinese Journal of Veterinary Parasitology 12: 111-116.

Domínguez, J., Panadero, R. \& De La Fuente-López, C. (2010). Detection of Hypoderma actaeon Infestation in Cervus elaphus with ELISA and Western Blotting. Journal of Wildlife Diseases 46: 934-938. https://doi.org/10.7589/0090-355846.3.934

Faliero, S., Otranto, D., Traversa, D., Giangaspero, A., Santagada, G., Lia, R. \& Puccini, V. (2001). Goat warble fly infestation by Przhevalskiana silenus (Diptera: Oestridae): immunoepidemiologic survey in the Basilicata region (southern Italy). Parassitologia 43: 131-134.

Hasan, M., Khan, M., Mushtaq, M., Iqbal, Z., Farooq, A., Sajid, M. \& Waheed, H. (2007). Prevalence of warble fly infestation in Buffalo in Chakwal, Punjab. Italian Journal of Animal Science 6: 942-944. https://doi.org/10.4081/ ijas.2007.s2.942

Hasnain, H. (1985). Sheep and goats in Pakistan Animal Production Health. FAO.
Hassan, M.U., Khan, M.N., Abubakar, M., Waheed, H.M., Iqbal, Z. \& Hussain, M. (2010). Bovine hypodermosis-a global aspect. Tropical Animal Health and Production 42: 1615-1625. https://doi.org/10.1007/s11250-010-9634-y

Hourrigan, J. (1979). Spread and detection of psoroptic scabies of cattle in the United States. Journal of American Veterinary Association 175: 1278-1280.

Jan, S., Lateef, M., Abbas, F., Maqbool, A., Jabbar, M.A., Kakar, H., Razzaq, A., Shah, S.H. \& Kakar, E. (2014). Seroepidemiological studies on goat hypodermosis in northern upland Balochistan, Pakistan. Pakistan Journal of Zoology 46: 153-160.

Khan, A.W. (1969). Animal production. Ilmi book depot canal park road, Lahore pp 779-814.

Khan, M., Akhtar, S. \& Cheema, A. (1994). Efficacy of ivermectin against goat warbles (Przhevalskiana silenus Brauer) in Pakistan. Veterinary Record 135: 361. https://doi.org/10.1136/ vr.135.15.361

Khan, M.Q. (1997). Efficacy of ivermectin against cattle warbles in Pakistan. Acta Parasitologica 42: 173-175.

Khan, M.Q., Cheema, A.H. \& Munir, M. (1997). Prevalence and treatment of goat warbles in Taunsa and Barkhan area. Pakistan Veterinary Journal 17: 82-84.

Khan, M., Iqbal, Z., Sajid, M., Anwar, M., Needham, G. \& Hassan, M. (2006). Bovine hypodermosis: Prevalence and economic significance in southern Punjab, Pakistan. Veterinary Parasitology 141: 386-390. https://doi.org/10.1016/ j.vetpar.2006.05.014

Morsy, T.A., Farrag, A., Mazyad, S. \& Abou-Gamra, M. (1999). Evaluation of ELISA kit hypodermosis in serodiagnosis of Przhevalskiana silenus in goats and Cephalopenia titillator in camels. Journal of the Egyptian Society of Parasitology 29: 709-719.

Navidpour, S., Madani, R., Goodarzi, M.A. \& Paykari, H. (2007). Study of antibodies development in naturally infested goats by Przhevalskiana sp. using by ELISA kit. Journal of Experimental Zoology, India 10: 301-303.

Nizami, M., Shafiq, M., Rashid, A. \& Aslam, M. (2004). The soils and their agricultural development potential in Pothwar. NARC, 1405: 3195.

Oryan, A. \& Bahrami, S. (2012). Pathology of natural Przhevalskiana silenus infestation in goats. Tropical Biomedicine 29: 524-531.

Oryan, A., Razavi, S. \& Bahrami, S. (2009). Occurrence and biology of goat warble fly infestation by Przhevalskiana Silenus (Diptera, Oestridae) in Iran. Veterinary parasitology 166: 178-181. https://doi.org/10.1016/j.vetpar.2009.07.036

Otify, Y. \& Mansour, N. (1994). Hypodermatosis among animals furnishing meat production in Green Mountain-Libya. Assiut Veterinary Medical Journal 32: 54-54.

Otranto, D., Boulard, C., Giangaspero, A., Caringella, M., Rimmele, D. \& Puccini, V. (1999). Serodiagnosis of goat warble fly infestation by Przhevalskiana silenus with a commercial ELISA kit. Veterinary Record 144: 726-729. https://doi.org/10.1136/vr.144.26.726

Otranto, D. \& Puccini, V. (2000). Further evidence on the internal life cycle of Przhevalskiana silenus (Diptera, Oestridae). Veterinary Parasitology 88: 321-328. https://doi.org/10.1016/ S0304-4017(99)00214-9

Otranto, D., Testini, G., Sottili, R., Capelli, G. \& Puccini, V. (2001). Screening of commercial milk samples using ELISA for immuno-epidemiological evidence of infection by the cattle grub (Diptera: Oestridae). Veterinary Parasitology 99: 241-248. https://doi.org/10.1016/S0304-4017(01)00463-0 
Otranto, D., Zalla, P., Testini, G. \& Zanaj, S. (2005). Cattle grub infestation by Hypoderma sp. in Albania and risks for European countries. Veterinary Parasitology 128: 157-162. https://doi.org/10.1016/j.vetpar.2004.11.016

Panadero, R., Martínez Carrasco, C., León Vizcaíno, L., López, C., DÍEZ BAÑOS, P., Morrondo, M. \& Alonso, F. (2010). Use of a crude extract or purified antigen from first instar cattle grubs, Hypoderma lineatum, for the detection of anti Hypoderma antibodies in free ranging cervids from southern Spain. Medical and Veterinary Entomology 24: 418424. https://doi.org/10.1111/j.1365-2915.2010.00892.x

Puente, S., Otranto, D., Panadero, R., Herrero, M.D., Rivas, P., Ramírez Olivencia, G., Mariscal, J.R.C., Perteguer, M.J., Díez Baños, P. \& Gárate, T. (2010). First diagnosis of an imported human myiasis caused by Hypoderma sinense (Diptera: Oestridae), detected in a European traveler returning from India. Journal of Travel Medicine 17: 419-423. https:// doi.org/10.1111/j.1708-8305.2010.00464.x

Radfar, M.H. \& Hajmohammadi, V. (2012). Prevalence of goatwarble fly, Przhevalskiana silenus in southeastern of Iran. Science Parasitology 13: 73-76.

Rahbari, S. \& Ghasemi, J. (1997). Study on economic aspects of goat grubs in Iran. Tropical Animal Health and Production 29: 243-244. https://doi.org/10.1007/BF02632313
Scholl, P.J. (1993). Biology and control of cattle grubs. Annual Review of Entomology 3: 53-70. https://doi.org/10.1146/ annurev.en.38.010193.000413

Shah, S. (1981). Incidence of warble fly in livestock population of NWFP (Pakistan). Journal of Animal Health and Production 3: $43-48$.

Sinclair, I., Tarry, D. \& Wassall, D. (1984). Persistence of antibody in calves after an infection with Hypoderma bovis. Research in Veterinary Science 37: 383-384. https:// doi.org/10.1016/S0034-5288(18)31891-5

Tavassoli, M., Tajik, H., Yaghobzadeh, K.R. \& Javadi, S. (2010). Prevalence of Goat Warble Fly, Przhevalskiana spp. (Dipetra: Oestridae), in West Azarbaijan, Iran. Iranian Journal of Veterinary Science and Technology 2: 33-38.

Webster, K., Giles, M. \& Dawson, C. (1997). A competitive ELISA for the serodiagnosis of hypodermosis. Veterinary Parasitology 68: 155-164. https://doi.org/10.1016/S03044017(96)01062-X

Yadav, A., Khajuria, J. \& Soodan, J. (2006). Warble fly infestation in goats of Jammu. Journal of Veterinary Parasitology 20: 149-152.

Yadav, A., Katoch, R., Khajuria, J., Katoch, M. \& Agrawal, R. (2011). Prevalence and biology of goat warble fly infestation by Przhevalskiana silenus in Jammu province, India. Tropical Animal Health and Production 43: 1487-1492. https://doi.org/10.1007/s11250-011-9813-5 